Przegląd Badań Edukacyjnych Educational Studies Review

ISSN 1895-4308

nr 25 (2/2017), s. 247-265

ORYGINALNE ARTYKULY BADAWCZE

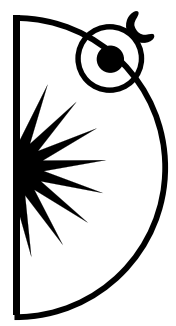

Beata Przyborowska

Uniwersytet Mikołaja Kopernika w Toruniu, e-mail: bprzybor@post.pl

Iwona Murawska

Uniwersytet Mikołaja Kopernika w Toruniu, e-mail: murawska_i@wp.pl

\title{
Między konformizmem a innowacyjnością. Z badań nad strategiami uczniowskimi
}

DOI: http://dx.doi.org/10.12775/PBE.2017.029

\section{Between Conformism and Innovativeness . From Studies on Students' Stragies}

\section{Abstract}

The presented text aims at answering the question what strategies the youth use nowadays in order to adapt to school and to the role of a student. In the present research Merton's theory on deviance was used. The text presents the results of a study which shows the two most often used by students strategies: conformism and innovativeness. The study was conducted with the use of the quantitative strategy, in a comparative diagram and the method used was surveys. It was done on a representative group of 656 students. The presented analysis is a part of bigger research on middle-schoolers' student strategies.

Keywords: startegies, R.K. Merton, conformism, innovativeness, youth.

\section{Wprowadzenie}

Niniejszy tekst jest próbą włączenia się do debaty na temat kondycji współczesnej młodzieży i instytucji edukacyjnej jaką jest/było gimnazjum. Podjęta problematyka jest ważna nie tylko w aspekcie poznawczym, ale również prak- 
tycznym. W rodzimej pedagogice obszar badań nad uczniowskimi strategiami adaptacji do szkoły i roli ucznia uznajemy za zaniedbany. Dostępne badania dotyczące uczniowskich strategii przystosowania to głównie prace przywoływane przez A. Janowskiego (1989), które dotyczą społeczności brytyjskich szkół sprzed kilkudziesięciu lat. Podkreślano tam, jak bardzo uczniowie są wycofani, a także jak często muszą sobie radzić ze szkołą, i jak bardzo szkołę kontestują.

Prezentowane w niniejszym artykule badania są ważne również dla praktyki edukacyjnej: dla diagnozy środowiska szkolnego, jakim jest/było gimnazjum a także dla oceny kondycji współczesnej młodzieży. W dyskursie potocznym i w praktyce edukacyjnej utrwaliło się wiele mitów i stereotypów na temat młodzieży gimnazjalnej, które warto zweryfikować w badaniach.

Trudno pisać o współczesnych nastolatkach bez zwracania uwagi na zmiany zachodzące szybciej niż kiedykolwiek, w różnych sferach praktyk społecznych i życiu człowieka. Dokonują się przeobrażenia w strukturze otoczenia, stylach życia czy w sposobach funkcjonowania wśród innych ludzi (por. Błajet, 2016). Szkoła jest w dalszym ciągu ważną instytucją w procesie socjalizacji, jednak nie posiada ona wyłączności w konstrukcji młodzieńczej tożsamości (Bardziejewska, 2005, s. 365-366). Nie bez znaczenia pozostają wszelkie środki masowego przekazu, w tym szczególnie portale społecznościowe, które na stałe wpisują się w kanony życia w świecie wirtualnym i pozawirtualnym (o ile można jeszcze te sfery traktować rozłącznie). Wielopłaszczyznowość, niejasność i spektrum dokonujących się zmian może wpływać na funkcjonowanie młodzieży w zakresie samoidentyfikacji i konstruowania tożsamości. Młody człowiek staje się jednostką wiecznie poszukującą i nieustannie dookreślającą siebie (Cybal-Michalska, 2006, s. 146-147). Jednak dzięki tym poszukiwaniom i umiejętności budowania za każdym razem na nowo swojej tożsamości, adolescent staje się zdolny do adaptacji zawsze i wszędzie, bez większym problemów czy sentymentów. Współczesny (określany mianem globalnego) nastolatek jest bardzo praktyczny, nie ma też problemów z komunikacją. Jest otwarty na świat i nowe doświadczenia (Melosik, 2013, s. 142-143).

Współcześni dorastający są przedstawicielami nowej generacji, która okres dorastania przeżywa $\mathrm{w}$ nowej rzeczywistości kulturowej. W tym kontekście warto podkreślić, że pokolenie to nie tylko wspólnota wieku, a także podobieństwa w zakresie postaw, upodobań, wartości, na które złożyło się funkcjonowanie w określonej rzeczywistości społeczno-kulturowej (Griese 1996, s. 80). Jeszcze kilkanaście lat temu o młodzieży pisało się często w aspekcie buntu czy subkultur. Dziś temat ten, choć wciąż ważny, zdaje się dezaktualizować. Mamy 
do czynienia z pewną unifikacją, a potrzeba przynależności do grupy wiąże się $\mathrm{z}$ byciem niemalże jednakowym.

Człowiek szczególnie jest uwikłany w sieć otaczających go z wielu stron współwystępujących sprzecznych kategorii, przekazów czy modalności. Z jednej strony otacza go wszechobecny pluralizm, który jest przeplatany możliwością selektywnej autoprezentacji w Internecie. Takim sprzecznym mechanizmom podlega również funkcjonowanie w przestrzeni instytucji, przeciwstawiane sferze autokreacji, wyboru i niemalże nieograniczonej wolności konstruowania siebie i konsumowania;choć może być to jedynie wolność pozorna (Melosik, 2013). Młody człowiek funkcjonuje również w podzielonej przestrzeni aksjologicznej szkoły (Chomczyńska-Rubacha, Rubacha, 2016), gdzie systemy wartości uczestników procesu edukacji są często rozbieżne i sprzeczne .

W społeczeństwie narasta poczucie wyobcowania i niepewności. Dzisiejsza rzeczywistość oferuje coraz więcej destabilizacji, której towarzyszy duże ryzyko. We współczesnym świecie tempo zmian, dokonujących się w różnych płaszczyznach życia, wzmaga poczucie niepewności jutra, jednak nie tylko w obrębie jednostek, ale także organizacji, również edukacyjnych (Przyborowska, 2007).

\section{Założenia teoretyczne}

Analiza empiryczna strategii uczniowskich wymagała szerokiego ugruntowania teoretycznego, a także interdyscyplinarnego osadzenia. Wybrana do badań perspektywa teoretyczna odnosi się do funkcjonowania uczniów w szkole, stanowiąc część pewnego złożonego systemu. Szkoła jest tutaj traktowana jako pewne środowisko, zorganizowana część otoczenia społeczno-kulturowego, która odpowiada za przygotowanie uczniów do bycia częścią społeczeństwa, a także wdraża ich do bycia świadomymi odbiorcami i uczestnikami kultury. Szkoła rozumiana jest zarówno jako część struktury tego świata oraz jako pewne mikrospołeczeństwo, konstruujące własne zasady bycia.

Badając strategie uczniowskie można dostrzec ich uniwersalny charakter, każda $\mathrm{z}$ nich wiąże się bowiem z pewnym rodzajem postawy wobec szkoły, która równie dobrze mogłaby być postawą wobec świata społecznego. Definicja strategii jaką przyjęto na potrzeby tej pracy jest kompatybilna z podejściem Roberta K. Mertona, będąctym samym wynikiem traktowania szkoły jako instytucji wymagającej adaptacji. Traktuje więc strategie jako wyraz adaptacji lub jej braku. W takim rozumieniu strategii badania odwołują się do stylów indywidualnego przystosowania Mertona, które bezpośrednio wiążą się z przysto- 
sowaniem do zastanego środowiska społecznego, zawężając owe środowisko do szkolnego. Strategię w badaniach definiuje się, w kontekście teorii socjologicznej, jako sposób przystosowania się (adaptacji) ucznia do warunków środowiska szkolnego oraz oczekiwań i wymagań związanych z przyswojeniem roli ucznia.

Wśród strategii można odnaleźć zarówno postawy konformistyczne, jak i buntownicze, w twórczy sposób kontestujące szkołę oraz związane z przyzwyczajeniem czy wycofaniem, pewną szkolną rutyną. Przekonanie o związku postaw wobec świata z postawami wobec szkoły uzasadnia wybór teorii Mertona jako bazowej w świetle prowadzonych analiz. Teoria ta wskazuje dwa zasadnicze komponenty struktury społecznej i kulturowej jako mające dla niej szczególne i bezpośrednie znaczenie: cele kulturowe i środki do osiągania tych celów (Merton, 1982, s. 196-197). Cele kulturowe nie zawsze pozostają w nieustannym związku ze sposobami ich realizacji, a wzajemna równowaga utrzymywana jest do czasu osiągania zadowolenia $\mathrm{z}$ danego stanu. Tym samym jednostki lub grupy wciąż przystosowują się do nowych warunków społeczno-kulturowych, a wśród sposobów owego przystosowania Merton wyróżnia: konformizm, innowacyjność, rytualizm, wycofywanie się, buntowniczość (Merton, 1982, s. 198-203).

Konformizm, jest sposobem przystosowania, który akceptuje zarówno cele, jak i środki. Postawy konformistyczne są odpowiedzialne za mechanizmy utrwalania i przekazywania wartości danej kultury. Uczniowie, których cechuje postawa konformistyczna, wierzą w cel i istotę działania szkoły, a także zasadniczo akceptują środki, które do niego prowadzą. Postawa innowacyjna charakteryzuje się akceptacją celu, jednak z jednoczesnym odrzuceniem środków do niego prowadzących. Dostępne środki są zastępowane nowymi, adekwatnymi do aktualnej potrzeby, często nietypowymi czy nieakceptowanymi. Wskazana ambicja celu może wzmagać postawy nowatorskie, ale wiąże się z nią również pewne zagrożenie dewiacji i chorobliwych dążeń. Szkolni innowatorzy to osoby wierzące $\mathrm{w}$ misję edukacji, często pomysłowe i poddające $\mathrm{w}$ wątpliwość metody pracy szkoły, które niekiedy bywają dla nich za mało efektywne. Rytualizm jest postawą, która polega na akceptacji środków, jednak bez internalizacji celu. Postawy rytualistyczne pomagają przetrwać szkolny dzień i charakteryzują osoby, które nie wierzą w misję szkoły, jednak dla własnej wygody stosują się do zastanych środków; osoby o zaniżonych ambicjach, często obojętne w stosunku do szkoły. Strategie wycofania wiąże się z odrzuceniem zarówno środków jak i celów szkoły. Osoby stosujące tą strategię, są jakby poza społecznością, z jednej strony znajdują się w niej, z drugiej strony jakby w niej 
nie były. Z kolei bunt, umożliwia uczniom wyjść na zewnątrz szkolnej struktury w celu realizacji jej od nowa. Zakłada on wyobcowanie ze znanych celów i środków, kiedy system staje się przeszkodą w ich realizacji, wtedy sytuacja dojrzewa do buntu w formie adaptacyjnej (Merton, 1982, s. 203-220).

\section{Założenia metodologiczne badań własnych}

Prezentowane wyniki są częścią szerszych badań dotyczących strategii uczniowskich gimnazjalistów. Przedmiotem badań były strategie uczniowskie w gimnazjach o zróżnicowanym potencjale edukacyjnym. W pracy badawczej poszukiwano odpowiedzi na dwa kluczowe pytania: jakie strategie przystosowania stosują gimnazjaliści wobec szkoły i roli ucznia w szkołach o zróżnicowanym potencjale edukacyjnym? Jakie są różnice w średnich wynikach skali mierzącej strategie uczniowskie pomiędzy szkołami o zróżnicowanym potencjale edukacyjnym?

Badania mieściły się w schemacie porównwczym i prowadzono je w oparciu o strategię ilościową, a wyjaśnienia jakie uzyskano miały charakter nomotetyczny. Zastosowaną metodą było ankietowanie. Badania przeprowadzono przy użyciu autorskiego narzędzia - skali do mierzenia strategii uczniowskich (I. Murawska), opartą na teorii przystosowania społecznego Mertona, uwzględniającej współczesne konteksty edukacyjne. Skala obejmowała kontinuum odpowiedzi od 1 (,zdecydowanie nie zgadzam się ze stwierdzeniem”) do 5 (,zdecydowanie zgadzam się z prezentowanym stwierdzeniem"). Każda ze strategii była reprezentowana kolejno przez 6 stwierdzeń. Badania właściwe zostały poprzedzone pilotażem, przeprowadzonym na grupie 179 osób (łącznie 9 klas), w szkołach innych niż wylosowane bo badań właściwych. Pilotaż pozwolił na eliminację niedoprecyzowanych i niezrozumiałych dla uczniów stwierdzeń, które nie stanowiły właściwej operacjonalizacji zmiennych i nie badały właściwych cech. Po badaniach pilotażowych, przeprowadzono badania właściwie wśród uczniów 12 szkół województwa kujawsko-pomorskiego wylosowanych zgodnie z proporcjami występowania danego typu szkoły na podstawie EWD w województwie spośród uprzednio przygotowanych list. Zbadano reprezentatywną próbę 656 uczniów województwa kujawsko-pomorskiego z losowo wybranych szkół o różnym potencjale edukacyjnym. Badania prowadzone było od maja 2016 do marca 2017 roku.

Pośród pięciu wyróżnionych przez Mertona strategii (konformizm, innowacyjność, rytualizm, buntowniczość i wycofywanie się), to właśnie stwierdzenia odnoszące się do strategii innowacyjności i konformizmu osiągnęly 
najwyższe średnie w populacji badanych, zatem są najliczniej reprezentowane przez młodzież. Dlatego też zdecydowałyśmy się szerzej zinterpretować te wyniki, które zaprzeczają obiegowym sądom na temat uczniów gimnazjów, które w świetle oceny opinii publicznej i obecnego Ministerstwa Edukacji Narodowej były niekorzystnym środowiskiem wychowawczym dla młodzieży.

\section{Wyniki badań}

\section{Młodzież a konformizm}

Aby uzyskać informacje na temat stosowania strategii „konformizm” przez uczniów, zastosowano narzędzie badawcze, w którym strategia ta była reprezentowana przez sześć stwierdzeń. Wyniki zawarto w poniższych tabelach.

Tabela 1. Wyniki ogólne dla strategii konformizmu.

\begin{tabular}{|l|c|c|}
\hline \multicolumn{1}{|c|}{ Kategorie odpowiedzi } & N & $\%$ \\
\hline Zdecydowanie się nie zgadzam & 441 & 11,207 \\
\hline Nie zgadzam się & 540 & 13,723 \\
\hline Nie mam zdania & 955 & 24,269 \\
\hline Zgadzam się & 1326 & 33,698 \\
\hline Zdecydowanie się zgadzam & 673 & 17,103 \\
\hline Suma & 3935 & 100 \\
\hline
\end{tabular}

Źródło: badania własne.

Tabela 2. Statystyki opisowe dla strategii konformizmu.

\begin{tabular}{|c|c|c|c|c|}
\hline Średnia & Mediana & Dominanta & Odchylenie & Skośność \\
\hline 3,335 & 4 & 4 & 1,215 & $-0,438$ \\
\hline
\end{tabular}

Źródło: badania własne.

Średnia dla strategii konformizmu wynosi 3,335, a mediana i dominanta są równe 4 (tabela 2). Wyniki te wskazują na ogólny wysoki poziom identyfikacji ze stwierdzeniami odnoszącymi się do konformizmu. Wśród ogółu odpowiedzi uczniów na pytania dotyczące strategii konformizmu dominuje kategoria ,zgadzam się", która odnosi się do co trzeciej odpowiedzi. Łącznie ponad połowa odpowiedzi sytuuje się wokół wartości aprobujących, a co czwarta wokół przeczących (tabela 1). 
Tabela 3. Stwierdzenie: „Kiedy nauczyciel wydaje polecenia, zazwyczaj bez namysłu je wykonuję".

\begin{tabular}{|l|c|c|}
\hline \multicolumn{1}{|c|}{ Kategorie odpowiedzi } & N & $\%$ \\
\hline Zdecydowanie się nie zgadzam & 71 & 10,940 \\
\hline Nie zgadzam się & 139 & 21,418 \\
\hline Nie mam zdania & 146 & 22,496 \\
\hline Zgadzam się & 220 & 33,898 \\
\hline Zdecydowanie się zgadzam & 73 & 11,248 \\
\hline Suma & 649 & 100 \\
\hline
\end{tabular}

Źródło: badania własne.

Z danych zamieszonych w tabeli 3 wynika, że 45\% uczniów wszystkich badanych szkół deklaruje wykonywanie polecenia wydanego przez nauczyciela bez namysłu.

Tabela 4. Stwierdzenie: „Kiedy nauczyciel wydaje polecenia, zazwyczaj bez namysłu je wykonuję". Statystyki opisowe.

\begin{tabular}{|c|c|c|c|c|}
\hline Średnia & Mediana & Dominanta & Odchylenie & Skośność \\
\hline 3,131 & 3 & 4 & 1,194 & $-0,243$ \\
\hline
\end{tabular}

Źródło: badania własne.

Średnia dla tego stwierdzenia wynosi niewiele ponad 3, a wartość środkowa 3. Odpowiedzią na skali, którą najczęściej zaznaczali uczniowie jest 4 (tabela 4). Wyniki świadczą o lewostronnej asymetrii rozkładu.

Tabela 5. Stwierdzenie: „W szkole nauczyciel ma najczęściej rację”.

\begin{tabular}{|l|l|l|}
\hline \multicolumn{1}{|c|}{ Kategorie odpowiedzi } & \multicolumn{1}{c|}{ N } \\
\hline Zdecydowanie się nie zgadzam & 96 & 14,634 \\
\hline Nie zgadzam się & 134 & 20,427 \\
\hline Nie mam zdania & 181 & 27,591 \\
\hline Zgadzam się & 171 & 26,067 \\
\hline Zdecydowanie się zgadzam & 74 & 11,280 \\
\hline Suma & 656 & 100 \\
\hline
\end{tabular}

Źródło: badania własne. 
Ponad 37\% uczniów uważa, że w szkole nauczyciel ma najczęściej rację, przeciwnego zdania jest 35\% uczniów (tabela 5).

Tabela 6. Stwierdzenie: „W szkole nauczyciel ma najczęściej rację”. Statystyki opisowe.

\begin{tabular}{|c|c|c|c|c|}
\hline Średnia & Mediana & Dominanta & Odchylenie & Skośność \\
\hline 2,989 & 3 & 3 & 1,226 & $-0,089$ \\
\hline
\end{tabular}

Źródło: badania własne.

Średnia dla powyższego stwierdzenia plasuje się poniżej wartości 3. Odpowiedzią na skali, którą najczęściej zaznaczali uczniowie jest 3 (tabela 6). Uzyskane wyniki wskazują na lewostronną asymetrię rozkładu.

Tabela 7. Stwierdzenie: „Lubię chodzić do mojej szkoły”.

\begin{tabular}{|l|c|c|}
\hline \multicolumn{1}{|c|}{ Kategorie odpowiedzi } & N & $\%$ \\
\hline Zdecydowanie się nie zgadzam & 118 & 18,098 \\
\hline Nie zgadzam się & 69 & 10,583 \\
\hline Nie mam zdania & 125 & 19,172 \\
\hline Zgadzam się & 219 & 33,589 \\
\hline Zdecydowanie się zgadzam & 121 & 18,558 \\
\hline Suma & 652 & 100 \\
\hline
\end{tabular}

Źródło: badania własne.

$\mathrm{Z}$ danych zamieszczonych $\mathrm{w}$ tabeli 7 wynika, że ponad połowa uczniów lubi chodzić do swojej szkoły. Co piąty uczeń nie ma zdania w tej kwestii, a niespełna co trzeci nie jest zadowolony z faktu, że musi uczęszczać do swojej szkoły.

Tabela 8. Stwierdzenie: „Lubię chodzić do mojej szkoły”. Statystyki opisowe.

\begin{tabular}{|c|c|c|c|c|}
\hline Średnia & Mediana & Dominanta & Odchylenie & Skośność \\
\hline 3,239 & 4 & 4 & 1,361 & $-0,428$ \\
\hline
\end{tabular}

Źródło: badania własne.

Średnia dla tego stwierdzenia wynosi 3,239. Zarówno mediana i dominanta wynoszą 4, to znaczy, że przeciętną, jak i najczęściej zaznaczaną wartością było 4 (zgadzam się) (tabela 8). Wyniki świadczą o lewostronnej asymetrii rozkładu. 
Tabela 9. Stwierdzenie: „Moim zdaniem szkoła do której chodzę w satysfakcjonujący dla mnie sposób realizuje swoje zadania".

\begin{tabular}{|l|c|c|}
\hline \multicolumn{1}{|c|}{ Kategorie odpowiedzi } & N & $\%$ \\
\hline Zdecydowanie się nie zgadzam & 42 & 6,422 \\
\hline Nie zgadzam się & 73 & 11,162 \\
\hline Nie mam zdania & 231 & 35,321 \\
\hline Zgadzam się & 216 & 33,028 \\
\hline Zdecydowanie się zgadzam & 92 & 14,067 \\
\hline Suma & 654 & 100 \\
\hline
\end{tabular}

Źródło: badania własne.

47\% uczniów jest zadowolonych z pracy swojej szkoły, odmienne zdanie ma ponad $17 \%$ gimnazjalistów, a 35\% uczniów nie ma w tej kwestii zdania (tabela 9).

Tabela 10. Stwierdzenie: „Moim zdaniem szkoła do której chodzę w satysfakcjonujący dla mnie sposób realizuje swoje zadania". Statystyki opisowe.

\begin{tabular}{|c|c|c|c|c|}
\hline Średnia & Mediana & Dominanta & Odchylenie & Skośność \\
\hline 3,372 & 3 & 3 & 1,061 & -0398 \\
\hline
\end{tabular}

Źródło: badania własne.

Średnia dla stwierdzenia odnoszącego się do satysfakcji z realizacji zadań przez szkołę jest stosunkowo wysoka, jednak zarówno mediana, jak i dominanta wynoszą 3 (tabela 10). Wyniki świadczą o lewostronnej asymetrii rozkładu.

Tabela 11. Stwierdzenie: „Z przekonania szanuję zasady panujące w szkole”.

\begin{tabular}{|l|c|c|}
\hline \multicolumn{1}{|c|}{ Kategorie odpowiedzi } & N & $\%$ \\
\hline Zdecydowanie się nie zgadzam & 48 & 7,407 \\
\hline Nie zgadzam się & 75 & 11,574 \\
\hline Nie mam zdania & 163 & 25,154 \\
\hline Zgadzam się & 267 & 41,204 \\
\hline Zdecydowanie się zgadzam & 95 & 14,660 \\
\hline Suma & 648 & 100 \\
\hline
\end{tabular}

Źródło: badania własne. 
Większość gimnazjalistów szanuje zasady panujące w swojej szkole, jednak 7\% badanych sytuuje się wobec nich w mocnej opozycji. Co czwarty uczeń deklaruje ambiwalentny stosunek do szkolnych zasad (tabela 11).

Tabela 12. Stwierdzenie: „Z przekonania szanuję zasady panujące w szkole”. Statystyki opisowe.

\begin{tabular}{|c|c|c|c|c|}
\hline Średnia & Mediana & Dominanta & Odchylenie & Skośność \\
\hline 3,441 & 4 & 4 & 1,103 & $-0,613$ \\
\hline
\end{tabular}

Źródło: badania własne.

Średni wynik dla odpowiedzi wszystkich gimnazjalistów odnośnie szacunku z przekonania do szkolnych zasad wynosi 3,441 a wartość średnia i najczęstsza to 4 (tabela 12). Wyniki świadczą o lewostronnej asymetrii rozkładu.

Tabela 13. Stwierdzenie: „Sądzę, że nauka w szkole przyniesie mi w dalszym życiu wiele korzyści".

\begin{tabular}{|l|c|c|}
\hline \multicolumn{1}{|c|}{ Kategorie odpowiedzi } & N & $\%$ \\
\hline Zdecydowanie się nie zgadzam & 36 & 5,573 \\
\hline Nie zgadzam się & 50 & 7,740 \\
\hline Nie mam zdania & 109 & 16,873 \\
\hline Zgadzam się & 233 & 36,068 \\
\hline Zdecydowanie się zgadzam & 218 & 33,746 \\
\hline Suma & 646 & 100 \\
\hline
\end{tabular}

Źródło: badania własne.

Prawie 70\% gimnazjalistów wierzy, że nauka w szkole przyniesie im w dalszym życiu wiele korzyści (w tym ponad $33 \%$ jest o tym przekonana), zatem ufa celom realizowanym przez swoją szkołę. Tylko co dwudziesty gimnazjalista sądzi, że nauka w szkole nie przyniesie mu absolutnie żadnych korzyści (tabela 13).

Tabela 14. Stwierdzenie: „Sądzę, że nauka w szkole przyniesie mi w dalszym życiu wiele korzyści". Statystyki opisowe.

\begin{tabular}{|c|c|c|c|c|}
\hline Średnia & Mediana & Dominanta & Odchylenie & Skośność \\
\hline 3,847 & 4 & 4 & 1,138 & $-0,924$ \\
\hline
\end{tabular}

Źródło: badania własne. 
Średnia dla stwierdzenia odnoszącego się do wiary w korzyści płynące z uczęszczania do szkoły jest wysoka i wynosi 3,847 . Mediana i dominanta są równe 4 (tabela 14). Wyniki świadczą o lewostronnej asymetrii rozkładu.

$\mathrm{Na}$ podstawie danych zamieszczonych w tabelach, odnoszących się do strategii konformizmu, można wnioskować, że uczniowie generalnie akceptują zarówno cele realizowane przez szkołę, jak i środki do nich prowadzące. Niektóre odpowiedzi mogą wskazywać na niską refleksyjność w obrębie działalności swojej szkoły i podporządkowanie o charakterze optymistycznym. Szkoła wraz ze swoimi zasadami jest raczej lubiana przez populację gimnazjalistów. Większość badanych wierzy w sensowność działań szkoły. Lewostronna asymetria rozkładu tylko potwierdza wysoki poziom konformizmu wśród uczniów. Obliczone średnie, mediany i dominanty dowodzą ogólnej wierze w cel, który towarzyszy nauce w szkole. Ta grupa badanych akceptuje metody jej działania, jak i zasady w niej panujące. Najwyższe wyniki dla tej strategii dotyczą perspektywy przyświecającej uczęszczaniu do szkoły, a także szacunku do szkolnych zasad. Relatywnie niżej w stosunku do pozostałych stwierdzeń wypadła akceptacja bez namysłu poleceń wydawanych przez nauczyciela. Uzyskane wyniki w pewnym stopniu demitologizują przeświadczenie o kontestacji przez gimnazjalistów wszystkiego, co jest związane ze szkołą, a szczególnie mit o nierespektowaniu zasad w niej obowiązujących.

\section{Młodzież a innowacyjność}

Aby uzyskać informacje na temat stosowania przez uczniów strategii „innowacyjność", wykorzystano narzędzie badawcze, w którym strategia ta była reprezentowana przez sześć stwierdzeń. Wyniki zawarto w poniższych tabelach.

Tabela 15. Wyniki ogólne dla strategii innowacyjności.

\begin{tabular}{|l|c|c|}
\hline \multicolumn{1}{|c|}{ Kategorie odpowiedzi } & N & $\%$ \\
\hline Zdecydowanie się nie zgadzam & 362 & 9,313 \\
\hline Nie zgadzam się & 455 & 11,706 \\
\hline Nie mam zdania & 1073 & 27,605 \\
\hline Zgadzam się & 1141 & 29,354 \\
\hline Zdecydowanie się zgadzam & 856 & 22,022 \\
\hline Suma & 3887 & 100 \\
\hline
\end{tabular}

Źródło: badania własne. 
Odpowiedzi uczniów na stwierdzenia odnoszące się do strategii innowacyjności plasują się na wysokim poziomie skali. Łącznie ponad połowa odpowiedzi sytuuje się wokół wartości aprobujących, a tylko co piąta wokół przeczących (tabela 15).

Tabela 16. Statystyki opisowe dla strategii innowacyjności.

\begin{tabular}{|c|c|c|c|c|}
\hline Średnia & Mediana & Dominanta & Odchylenie & Skośność \\
\hline 3,431 & 4 & 4 & 1,216 & $-0,443$ \\
\hline
\end{tabular}

Źródło: badania własne.

Średnia dla strategii innowacyjności wynosi 3,431, mediana i dominanta przyjmują wartość 4 (tabela 16), a skośność świadczy o lewostronnej asymetrii rozkładu.

Tabela 17. Stwierdzenie: „Z radością przyjmuję zadania, które mogę wykonać w wybrany przez siebie sposób.

\begin{tabular}{|l|c|c|}
\hline \multicolumn{1}{|c|}{ Katalog odpowiedzi } & N & $\%$ \\
\hline Zdecydowanie się nie zgadzam & 39 & 6,056 \\
\hline Nie zgadzam się & 53 & 8,230 \\
\hline Nie mam zdania & 128 & 19,876 \\
\hline Zgadzam się & 234 & 36,335 \\
\hline Zdecydowanie się zgadzam & 190 & 29,503 \\
\hline Suma & 644 & 100 \\
\hline
\end{tabular}

Źródło: badania własne.

Ponad 65\% ogółu badanych cieszy się, kiedy otrzymane zadania może wykonać w wybrany przez siebie sposób, takiej satysfakcji nie odczuwa natomiast $14 \%$ badanych. Co piąty badany nie ma zdania w tej kwestii (tabela 17).

Tabela 18. Stwierdzenie: „Z radością przyjmuję zadania, które mogę wykonać w wybrany przez siebie sposób". Statystyki opisowe.

\begin{tabular}{|c|c|c|c|c|}
\hline Średnia & Mediana & Dominanta & Odchylenie & Skośność \\
\hline 3,75 & 4 & 4 & 1,143 & $-0,808$ \\
\hline
\end{tabular}

Źródło: badania własne. 
Średnia dla powyższego stwierdzenia wśród ogółu badanych jest wysoka i wynosi aż 3,75. Zarówno mediana jak i dominanta wynoszą 4 (tabela 18), a asymetria ma charakter lewostronny.

Tabela 19. Stwierdzenie: „Lubię kiedy nauczyciel mnie zaskakuje”.

\begin{tabular}{|l|c|c|}
\hline \multicolumn{1}{|c|}{ Katalog odpowiedzi } & N & $\%$ \\
\hline Zdecydowanie się nie zgadzam & 79 & 12,098 \\
\hline Nie zgadzam się & 85 & 13,017 \\
\hline Nie mam zdania & 202 & 30,934 \\
\hline Zgadzam się & 181 & 27,718 \\
\hline Zdecydowanie się zgadzam & 106 & 16,233 \\
\hline Suma & 653 & 100 \\
\hline
\end{tabular}

Źródło: badania własne.

Uczniowie na ogół cieszą się, kiedy nauczyciel ich zaskakuje, jednak co czwarty uczeń nie lubi być zaskakiwany przez swojego nauczyciela (tabela 19), może to także wskazywać na fakt, że owe zaskoczenie kojarzy mu się z czymś (w jego ocenie) pejoratywnym.

Tabela 20. Stwierdzenie: „Lubię kiedy nauczyciel mnie zaskakuje”. Statystyki opisowe.

\begin{tabular}{|c|c|c|c|c|}
\hline Średnia & Mediana & Dominanta & Odchylenie & Skośność \\
\hline 3,230 & 3 & 3 & 1,221 & $-0,309$ \\
\hline
\end{tabular}

Źródło: badania własne.

Średnia dla sympatii z niespodzianek nauczyciela wynosi ogólnie 3,230, mediana i wartość najczęstsza wyniosły 3 (tabela 20), a asymetria ma charakter lewostronny.

Tabela 21. Stwierdzenie: „Uważam, że moja szkoła byłaby lepsza, gdyby nie bała się zmian".

\begin{tabular}{|l|c|c|}
\hline \multicolumn{1}{|c|}{ Katalog odpowiedzi } & N & $\%$ \\
\hline Zdecydowanie się nie zgadzam & 60 & 9,302 \\
\hline Nie zgadzam się & 51 & 7,907 \\
\hline Nie mam zdania & 209 & 32,403 \\
\hline Zgadzam się & 155 & 24,031 \\
\hline
\end{tabular}


Tabela 21. Stwierdzenie: „Uważam, że moja szkoła byłaby lepsza, gdyby nie bała się zmian".

\begin{tabular}{|l|c|c|}
\hline \multicolumn{1}{|c|}{ Katalog odpowiedzi } & N & $\%$ \\
\hline Zdecydowanie się zgadzam & 170 & 26,357 \\
\hline Suma & 645 & 100 \\
\hline
\end{tabular}

Źródło: badania własne.

Ponad 50\% uczniów deklaruje, że ich szkoła mogłaby funkcjonować lepiej, gdyby była bardziej otwarta na nowości, co trzeci uczeń nie ma w tej kwestii zdania, a co szósty nie podziela opinii dotyczącej korzystnego wpływu otwarcia się jego szkoły na nowości (tabela 21).

Tabela 22. Stwierdzenie: „Uważam, że moja szkoła byłaby lepsza, gdyby nie bała się zmian". Statystyki opisowe.

\begin{tabular}{|c|c|c|c|c|}
\hline Średnia & Mediana & Dominanta & Odchylenie & Skośność \\
\hline 3,502 & 4 & 3 & 1,223 & $-0,468$ \\
\hline
\end{tabular}

Źródło: badania własne.

Średnia dla stwierdzenia „Uważam, że moja szkoła byłaby lepsza, gdyby nie bała się zmian" jest wysoka i dla całej populacji wyniosła 3,5. Wartość centralna równa się 4, a najczęstsza 3 (tabela 22). Asymetria rozkładu jest lewostronna.

Tabela 23. Stwierdzenie: „Jestem w stanie nagiąć szkolne zasady jeżeli uznam, że moje działanie doprowadzi mnie do realizacji moich planów".

\begin{tabular}{|l|c|c|}
\hline \multicolumn{1}{|c|}{ Katalog odpowiedzi } & N & $\%$ \\
\hline Zdecydowanie się nie zgadzam & 66 & 10,185 \\
\hline Nie zgadzam się & 96 & 14,185 \\
\hline Nie mam zdania & 171 & 26,389 \\
\hline Zgadzam się & 180 & 27,778 \\
\hline Zdecydowanie się zgadzam & 135 & 20,833 \\
\hline Suma & 648 & 100 \\
\hline
\end{tabular}

Źródło: badania własne.

Prawie 50\% uczniów deklaruje, że jest w stanie nagiąć szkolne zasady dla realizacji swoich planów. Co czwarty uczeń nie nagiąłby szkolnych zasad. Wskazuje to na fakt, że uczniowie są w stanie zmienić środki, na rzecz ważne- 
go dla nich celu (tabela 23). Taka postawa może świadczyć o predyspozycji $\mathrm{z}$ jednej strony do zachowań innowacyjnych $-\mathrm{z}$ drugiej naginanie zasad może rodzić tendencję dość powszechną do oszukiwania (np. ściąganie, plagiaty).

Tabela 24. Stwierdzenie: „Jestem w stanie nagiąć szkolne zasady jeżeli uznam, że moje działanie doprowadzi mnie do realizacji moich planów". Statystyki opisowe.

\begin{tabular}{|c|c|c|c|c|}
\hline Średnia & Mediana & Dominanta & Odchylenie & Skośność \\
\hline 3,343 & 3 & 4 & 1,246 & $-0,338$ \\
\hline
\end{tabular}

Źródło: badania własne.

Średnia dla powyższego stwierdzenia wyniosła 3,343, a większość uczniów (o czym świadczy wartość dominanty) wskazała gotowość do potencjalnego naginania szkolnych zasad dla realizacji ważniejszych planów (tabela 24). Asymetria rozkładu ma w tym przypadku charakter lewostronny.

Tabela 25. Stwierdzenie: „W szkole często słyszę, że jestem twórczy/kreatywny”.

\begin{tabular}{|l|c|c|}
\hline \multicolumn{1}{|c|}{ Katalog odpowiedzi } & N & $\%$ \\
\hline Zdecydowanie się nie zgadzam & 94 & 14,619 \\
\hline Nie zgadzam się & 127 & 19,751 \\
\hline Nie mam zdania & 205 & 31,882 \\
\hline Zgadzam się & 150 & 23,328 \\
\hline Zdecydowanie się zgadzam & 67 & 10,420 \\
\hline Suma & 643 & 100 \\
\hline
\end{tabular}

Źródło: badania własne.

Co trzeci uczeń słyszy od członków społeczności szkolnej, że jest kreatywny, również co trzeci nie ma w tej kwestii zdania, jak i co trzeci nie spotyka się $\mathrm{z}$ takimi komentarzami w stosunku do swojej osoby (tabela 25).

Tabela 26. Stwierdzenie: „W szkole często słyszę, że jestem twórczy/kreatywny”. Statystyki opisowe.

\begin{tabular}{|c|c|c|c|c|}
\hline Średnia & Mediana & Dominanta & Odchylenie & Skośność \\
\hline 2,952 & 3 & 3 & 1,197 & $-0,055$ \\
\hline
\end{tabular}

Źródło: badania własne. 
Średnia dla stwierdzenia: „W szkole często słyszę, że jestem twórczy/kreatywny" wynosi 2,952. Wartość centralna i dominanta wynosi 3 (tabela 26). Asymetria rozkładu jest lewostronna.

Tabela 27. Stwierdzenie: „Cieszę się, kiedy mam możliwość zrobienia na zajęciach czegoś nowego, według mojego pomysłu".

\begin{tabular}{|l|c|c|}
\hline \multicolumn{1}{|c|}{ Katalog odpowiedzi } & N & $\%$ \\
\hline Zdecydowanie się nie zgadzam & 24 & 3,670 \\
\hline Nie zgadzam się & 43 & 6,575 \\
\hline Nie mam zdania & 158 & 24,159 \\
\hline Zgadzam się & 241 & 36,850 \\
\hline Zdecydowanie się zgadzam & 188 & 28,746 \\
\hline Suma & 654 & 100 \\
\hline
\end{tabular}

Źródło: badania własne.

Uczniowie odczuwają satysfakcję, kiedy podczas zajęć lekcyjnych mają możliwość pracy według własnego pomysłu. Taką radość deklaruje ponad 65\% badanych uczniów. Co dziesiąty uczeń nie odczuwa tej satysfakcji (tabela 27).

Tabela 28. Stwierdzenie: „Cieszę się, kiedy mam możliwość zrobienia na zajęciach czegoś nowego, według mojego pomysłu". Statystyki opisowe.

\begin{tabular}{|c|c|c|c|c|}
\hline Średnia & Mediana & Dominanta & Odchylenie & Skośność \\
\hline 3,804 & 4 & 4 & 1,042 & $-0,734$ \\
\hline
\end{tabular}

Źródło: badania własne.

Średnia dla powyższego stwierdzenia jest wysoka w populacji, bo wynosi aż 3,804. Zarówno mediana, jak i dominanta wynoszą 4 (tabela 28), a asymetria rozkładu jest zdecydowanie lewostronna.

Strategia innowacyjności (wraz z jej oczekiwaniem ze strony szkoły) sytuuje się generalnie na wysokim poziomie. Uczniowie, chociaż akceptują ogólne cele szkoły, oczekują przełamania szkolnej rutyny, chcą robić w szkole ciekawe (w ich opinii) rzeczy. Wielu z nich czeka na zmiany w swojej szkole, a także jest w stanie naginać zasady, jeżeli uzna to za znaczące dla realizacji swojego planu. To cieszy, ale również niepokoi w kontekście patologii szkolnych. Gimnazjaliści oczekują możliwości zrobienia na zajęciach czegoś nowego czy według własnego pomysłu. Jednak są średnio bardziej zdystansowani wobec niespodzianek przygotowywanych przez nauczyciela, prawdopodobnie przez możli- 
wość, że będzie to niezapowiedziany sprawdzian. Uczniowie w znacznym stopniu działają według reguł strategii innowacyjności - wierzą w cel i misję szkoły, jednak nie zawsze ufają środkom, które $\mathrm{z}$ chęcią by unowocześniali i urozmaicali. Z analizy otrzymanych danych można wnioskować, że szkolna codzienność wyzwala w uczniach kompetencje emancypacyjne, a także, że uczniowie chcieliby (choć w różnym stopniu, z różnym zaangażowaniem) zmieniać szkołę. Wyniki te potwierdzają badania E. Bilińskiej - Suchanek (2003, s. 269-276), która wskazała na opór transformatywny (czyli nastawiony na zmianę) jako dominantę wśród uczniowskich sposobów kontestacji.

\section{Dyskusja}

W świecie zdominowanym przez sprzeczne przekazy nie powinna nas dziwić możliwość bycia innowatorem i konformistą jednocześnie. Uczniowskie strategie zdają się być niejednoznaczne, jak i zmienne. Współczesny młody człowiek multiplikuje rzeczywistość, stąd nie zaskakuje taki rozkład występowania strategii. Przy ogólnej wierze w cel i misję społeczeństwa (w tym wypadku reprezentowanego przez szkołę), zróżnicowanie postaw dotyczy środków prowadzących do danego celu. Odzwierciedla to postawy młodych ludzi wobec świata, który powinien dostosować się ich oczekiwań, a także, zapewniając podstawową stabilizację, być otwarty na zmiany. Bowiem te, okazały się stałą, lecz paradoksalną konstrukcją rzeczywistości.

Jednakże w konfrontacji ze społecznym postrzeganiem osoby nastolatka rozkład wyników okazał się zaskoczeniem. Samo pojęcia nastolatka, osoby dorastającej, gimnazjalisty, jest często naznaczone w negatywny sposób. Konotacje, jakie posiadają te pojęcia, wiążą się z niedostosowaniem, obojętnością czy buntem kojarzonym z nieustającą ,rebelią” i podważaniem autorytetu. Taki obraz wzmacniają liczne medialne przekazy. Jednak niniejsze badania ukazały, że wśród dorastających przeważają strategie innowacyjne i konformistyczne. W klasycznym ujęciu Mertona, są to postawy osób, które wierzą w cele i misję danej instytucji/społeczności/kultury, przy czym innowatorzy pragną zmiany i unowocześnienia środków, a konformistom odpowiada zastany stan rzeczy, do którego odnoszą się w optymistycznie (Merton 1982).

W związku z uzyskanymi wynikami pojawia się refleksja, skąd taki obraz młodzieży? Być może jest to rezultat oddziaływania mediów, obecnych w sieci systemów eksperckich, czy wywierającego wpływ na społeczeństwo mechanizmu społecznej słuszności. Wyniki są przejrzyste i w tym kontekście pojawia się postulat porzucenia mitu sprzed kilkudziesięciu lat o zbuntowanym i wyco- 
fującym się nastolatku, gdyż nie przystaje on do aktualnej rzeczywistości, która od tego czasu zmieniła się już niezliczoną ilość razy.

Swoistą diagnozą nie tylko szkół, ale także oczekiwań uczniów, okazały się odpowiedzi na stwierdzenia dotyczące strategii innowacyjności. Większość uczniów bardzo ceni sobie możliwość rozwiązania zadania w wybrany przez siebie sposób (średnia 3,75), a także deklaruje chęć wykonania w szkole czegoś nowego. W związku ze szkolną pogonią za dobrymi wynikami egzaminów, w przestrzeń szkoły często wkrada się rutyna, zatem wszelkie nowe możliwości działania są oczekiwane przez uczniów. Ponadto, duża grupa uczniów twierdzi, że ich szkoła byłaby lepsza, gdyby nie bała się zmian (średnia 3,502). Większość uczniów szanuje szkolne zasady (średnia 3,441), a także wierzy w istotę działań szkoły (średnia 3,847). Gimnazjaliści ogółem są raczej zadowoleni $\mathrm{z}$ tego, jak ich szkoła realizuje swoje zadania $(3,372)$.

Badania, choć dotyczące województwa kujawsko-pomorskiego, z dużym prawdopodobieństwem mogą odzwierciedlać charakterystykę pokolenia współczesnej młodzieży. Grupy realizującej społeczne oczekiwania, raczej zintegrowanej i broniącej (choć nie zawsze) swoich racji. Jedno nie pozostawia wątpliwości: gimnazjaliści są w kontekście zmieniającego się świata bardziej „nowocześni” niż szkoła, która często frustruje uczniów swoimi tradycyjnymi metodami czy zasadami.

Poznanie sposobów adaptacji uczniów do szkolnej rzeczywistości stwarza możliwość zabrania głosu w debacie na temat młodzieży. Uzyskane w prowadzonych badaniach wyniki niejako obalają stereotyp złego i niezdolnego do współpracy gimnazjalisty. Większość uczniów deklaruje szacunek do szkoły i panujących w niej zasad, a także do osoby nauczyciela. W zamian oczekują jedynie tego samego. W związku z tym traktowanie gimnazjalisty jako dorastającego człowieka, który liczy na wsparcie i zrozumienie, może być kluczem do porozumienia pomiędzy grupami.

Uzyskane odpowiedzi wskazały także na większą potrzebę pracy twórczej z młodzieżą, a także docenienie ich pomysłów i głosu w podejmowanych kwestiach. Uczniowie w tych badaniach zwracali również częstona zaniedbanie komponentów wychowawczych szkoły, a także nauczycieli jako łamiących ustanowione przez siebie zasady. Uczniowie sugerowali również, że szkoła nie nadąża za zmianami dokonującymi się we współczesnym świecie, podkreślając, że rutynowe i przestarzałe metody są nieadekwatne i mało skuteczne.

Podsumowując: bardziej progresywistyczny model edukacji nastawiony na większą samodzielność i kreatywność ucznia, a także model innowacyjny otwarty na zmiany - mogłyby okazać się rozwiązaniami efektywnymi dla dora- 
stających uczniów (Schulz, 1996; Florida 2010; Przyborowska 2013), a w konsekwencji: dla zmieniającego się społeczeństwa coraz większej niepewności.

\section{Bibliografia}

Bardziejewska M. (2005). Okres dorastania. jak rozpoznać potencjał nastolatków, [w:] Brzezińska A.I. (red.). Psychologiczne portrety człowieka. Praktyczna psychologia rozwojowa. Gdańsk: Gdańskie Wydawnictwo Psychologiczne.

Bilińska-Suchanek E. (2003). Opór wobec szkoty. Dorastanie w perspektywie paradygmatu oporu. Kraków: Oficyna Wydawnicza „Impuls”.

Błajet P. (2016). (Nie)przypadkowa edukacja. Toruń: Wydawnictwo UMK.

Chomczyńska - Rubacha M, Rubacha K. (2016). Przestrzeń aksjologiczna szkoły. 1: Konstrukt teoretyczny. Przeglad Badań Edukacyjnych, nr 23.

Cybal-Michalska A. (2006). Tożsamość młodzieży w perspektywie globalnego świata. Studium socjopedagogiczne. Poznań: Wydawnictwo Naukowe UAM.

Florida R. (2010). Narodziny klasy kreatywnej oraz jej wplyw na przeobrażenia $w$ charakterze pracy, wypoczynku, społeczeństwa $i$ życia codziennego. Warszawa: Narodowe Centrum Kultury.

Griese H. M. (1996). Socjologiczne teorie młodzieży. Tłum. J. Dąbrowski, Kraków: Oficyna Wydawnicza „Impuls”.

Janowski A. (1989). Uczeń w teatrze życia szkolnego. Warszawa: Wydawnictwo Szkole i Pedagogiczne.

Melosik (2013). Kultura popularna i tożsamość młodzieży. W niewoli władzy $i$ wolności. Kraków: Oficyna Wydawnicza „Impuls”.

Merton R. K. (1982). Teoria socjologiczna i struktura społeczna. Tłum. E. Morawska, J. Wertenstein-Żuławski. Warszawa: Wydawnictwo Naukowe PWN.

Ostrowicka H. (2012). Urządzanie młodzieży. Studium analityczno-krytyczne. Kraków: Oficyna Wydawnicza „Impuls”.

Przyborowska B. (2007). Kultura organizacyjna oświaty w zmiennym otoczeniu. Olsztyn: Wyższa Szkoła Informatyki i Ekonomii TWP.

Przyborowska B. (2013). Pedagogika innowacyjności. Między teoria a praktyka. Toruń: Wydawnictwo Uniwersytetu Mikołaja Kopernika.

Schulz R. (1996). Studia z innowatyki pedagogicznej. Toruń, Wydawnictwo UMK. 
